\title{
Vinner man val med hjälp av historia? Nedslag i den svenska debatten inför riksdagsvalet 2014
}

\section{Niklas Ammert}

Slutsatsen av såväl andra världskriget som av det kalla kriget är att demokratierna måste hålla ihop.

Jan Björklund \& Carl Haglund, SvD 7 augusti 2014

Den svenska sjukvården har legat hos våra landsting ända sedan 1863. Det behöver knappast sägas att både samhället och vården har genomgått fundamentala förändringar sedan dess.

Göran Hägglund, SvD 30 juni 2014

Regeringen har förvandlat skolpolitiken till vilda västern [...]

Stefan Löfvén, SvD 29 juni 2014

Citaten belyser hur politiker i debatter ofta använder historia som exempel, som argument och som redskap. Kombattanterna hinner sällan passera mer än ett enda replikskifte förrän man ger varandra skulden för något som hände, eller inte hände, under förra eller förrförra mandatperioden. Det närliggande förflutna utgör därmed en direkt handlingsreferens. Historia används eller brukas också när politiska rörelser eller ideologier försöker muta in hela berättelser eller sammanhängande ideologiska arv. ${ }^{1}$ De nya moderaternas argumentation under det senaste årtiondet har inneburit att vörda det svenska folkhemmet och att kalla sig det nya arbetarpartiet, ett epitet som tidigare varit socialdemokraternas varumärke.

Analyser av politisk retorik visar att historia används i olika sammanhang och med olika syften. Att historia brukas som redskap är ingen nyhet, men historikern Anna Clark pekar på att intensiteten har ökat under senare år. ${ }^{2}$ Användningsområden och teman är både många och varierande: Australiens premiärminister Kevin Rudd bad 2008 landets ursprungsbefolkning om ursäkt för oförrätter i det förflutna, men vände samtidigt skulden och det historiska utanförskapet till ett argument för att skärpa kraven på att alla barn måste omfattas av det offentliga skolsystemet. Det gottgörande, eller ursäktande,

1 Knutsen, Ketil, "Political Frames of Welfare History” i Törnqvist-Plewa, Barbara \& Niklas Bernsand (red.), Painful Pasts and useful memories: Remembering and forgetting in Europe, Lund: Centre for European Studies (CFE) at Lund University 2012, s. $182 \mathrm{ff}$.

2 Clark, Anna, "Politicians Using History” i Australian Journal of Politics and History, Vol. 56, No. 1 2010., s. 119. 
historiebruket blev således med ens ett argumenterande och dagspolitiskt bruk i syfte att stärka den nationella skolpolitikens genomslagskraft. Historikern Ketil Knutsen visar i ett exempel från norsk inrikespolitik hur Fremskrittspartiets ledare Carl I Hagen använde historiska argument då han menade att det norska samhället hotas av muslimsk invandring. ${ }^{3}$ Historiska referenser kan således användas både i syfte att läka sår i samhället, för att påverka dagsaktuella frågor och för att bygga upp nya skiljelinjer eller motsättningar.

I en svensk kontext var historiens roll i samhället stor under 1900-talet, vilket bland annat märktes i en betydande utgivning av Sverigehistorier under 1960- och 70-talen.

När det gäller politiskt historiebruk har främst SAP, det parti som under huvuddelen av 1900-talet innehade makten, studerats. Internt har partiet odlat arbetarrörelsens historia, men ur ett vidare perspektiv motiverade man efter andra världskriget och framåt sin politik med framstegsanda och modernitet som ledstjärna. Det förflutna förknippades med vurm för stormaktstid, traditioner och konservatism och tjänade främst som en kontrast till det modernas framsteg och det nya samhället. ${ }^{4}$ Ointresset för historia blev en integrerad del av en modernistisk världsbild som i Sverige fick stort genomslag. ${ }^{5}$ Det finns i den hittillsvarande forskningen en tes om en omvänd relation mellan ett samhälles moderniseringsgrad och dess intresse för historia. Den stora europeiska undersökningen Youth and History från mitten av 1990-talet påvisar ett sådant samband: ”The more a country is modernized, the more it's students are demotivated to learn history.”6 Sedan några årtionden tillbaka finns det dock anledning att ifrågasätta detta samband. Den historiska dimensionen har, inte minst i populärvetenskap och media, återuppväckts i det svenska samhället. Den enorma floran av historiska magasin, liksom TV-program som Martin Timell och Dick Harrissons Sveriges historia eller Historieätarna är exempel på detta. Yttre händelser såsom kalla krigets slut, ekonomiska påfrestningar, EU-medlemskapet och inte minst tecknen på ett auktoritärt och expansivt Ryssland har med all sannolikhet verkat pådrivande på denna utveckling. Mot bakgrund av det långvariga modernistiska ointresset skulle man emellertid också kunna påstå att svenskarnas nutida intresse för historia helt enkelt svarar mot ett uppdämt behov. Det förflutna spelar åter en viktig roll för människor när det gäller att skapa förståelse och mening i tillvaron samt att forma tankar om framtiden. Huruvida detta återspeglas i den politiska argumentationen i en valrörelse vet vi dock mindre om.

3 Knutsen, Ketil, "Historiefortelling som politisk retorikk - En analyse av politiske taler, i Dessingué, Alexandre, Ketil Knutsen \& Ann Elisabeth Laksfoss Hansen (red.), Flerstemte minner, Hertervig Akademisk Forlag 2010, s. 4-8.

4 Zander, Ulf, Fornstora dagar, moderna tider: Bruk av och debater om svensk historia från sekelskifte till sekelskifte, Lund: Nordic Academic Press 2001, s. 462, 465-467 och 469.

5 Karlsson, Klas-Göran, ”Historia och samhälle - exemplet det moderna Sverige”, i Peter Elmlund \& Kay Glans (red.), Den välsignade tillväxten. Tankelinjer kring ett århundrade av kapitalism, teknik, kultur och vetenskap, Stockholm: Natur och Kultur 1998, s. 201-213.

6 von Borries, Bodo \& Magne Angvik (eds.), Youth And History, Volume A, Hamburg: Körber Stiftung 1997, s. 72. I studien har 31000 femtonåringar från 27 stater i Europa samt Isarel besvarat frågor om historieundervisning och historia i vid bemärkelse. Resultaten presenteras både generellt och för respektive region och stat. 
Det politiska historiebruket studeras vanligen i ledande politikers memoarer, linjetal eller enstaka debatter. Till detta fogas här svenska partiledares debattartiklar, vilka - åtminstone i Sverige - är en central arena för att formulera idéer eller presentera politiska utspel direkt till väljarna. Denna korta studie behandlar hur svenska partiledare använde historia i debattartiklar i Dagens Nyheter och Svenska Dagbladet under den dynamiska perioden de tre sista månaderna (14 juni till och med 14 september) före valet till riksdagen i september 2014.

Huruvida debattartiklarna får genomslag i valresultatet är självfallet svårare att uttala sig om. Valrörelser är kommunikativa processer i vilka politiker via flera kanaler försöker etablera en kontakt med potentiella väljare och genom denna kontakt övertyga om sitt budskap. I relationen mellan politiker och väljare finns också en dimension av samspel där de folkvalda lyssnar till väljarens problem eller frågor, men i själva valrörelsen och i debatten inför valet är det dock politikerna som agerar och artikulerar sitt budskap. För att budskapet ska nå fram och för att mottagaren ska kunna förhålla sig till det måste det, enligt medieforskaren Jesper Strömbäck, vara såväl igenkänningsbart som förståeligt och helst också upplevas som relevant.7 När man hänvisar till historiska referenser är dessa valda för att vara just igenkänningsbara av så många som möjligt. Här finns emellertid två vägar att gå: Den ena innebär att välja neutrala och allmänt kända exempel istället för värde- och konfliktladdade sådana. Syftet är att fler människor ska känna igen sig och att flera ska attraheras av budskapet. ${ }^{8}$ Den andra vägen innebär att välja just tydligt laddade och argumenterande referenser som skärper ställningstaganden i relation till meningsmotståndaren. Tidigare forskning visar att allmänna och förankrande exempel används i den politiska retoriken då det rör sig om linjetal eller mera enkelriktade uttalanden. När det handlar om debatter är de historiska referenserna mer av den argumenterande typen. ${ }^{9}$

Användandet, eller bruket, av historia kan systematiseras och analyseras med hjälp av typologier eller modeller som belyser typ av historiebruk, vem som är brukare, vilket syfte hon har och vilket behov som finns hos brukare och mottagare. ${ }^{10}$ I detta sammanhang är det ställt utom allt tvivel att det är politiker som brukar historia och att det görs i syfte att övertyga väljarna om den egna politikens fördelar, gärna som ett led i en gynnsam historisk utveckling eller som ett brott i den utveckling som motståndaren företräder. Historia används symboliskt, ideologiskt och normativt. Det finns således inte behov av att redovisa en fullständig analys av historiebruk. Karl-Georg Faber har studerat politiska debatter i tysk kontext och analyserat historiebruket med avseende på djupet i de

7 Strömbäck, Jesper \& Lars Nord (red,), Kampen om opinionen: Politisk kommunikation under svenska valrörelser, Stockholm: SNS förlag 2013, s. $10 \mathrm{ff}$.

8 Sigrell, Anders, Att övertyga mellan raderna: en retorisk studie av underförstådda inslag i modern politisk kommunikation, Umeå: Institutionen för nordiska språk, Umeå universitet 1999, s. 308.

9 Faber, Karl-Georg, "The Use of History in Political Debate” i History and Theory, Vol. 17, No. 4 1978, s. 59.

10 Karlsson, Klas-Göran, Historia som vapen: Historiebruk och Sovjetunionens upplösning 19851995, Stockholm: Natur och Kultur 1999, Aronsson, Peter, Historiebruk: att använda det förflutna, Lund: Studentlitteratur 2004. 
historiska referenserna. På en ytlig nivå används historia för att exemplifiera medan det på en mellannivå handlar om att skapa förståelse genom att man knyter an till meningsbärande berättelser eller redovisar tolkningar. På den djupare och mer genomarbetade nivån fungerar historia som argument för den egna linjen eller emot motståndarens. ${ }^{11}$ Modellen är användbar som en yttre analysram i min studie. Därtill görs en indelning av historiebruken som endera av a) ett positivt och förankrande historiebruk eller b) ett negativt utmärkande - eller rentav avskräckande - historiebruk.

Begreppet historia är omfattande och här avses två övergripande aspekter av historia, de korta linjernas historia respektive de längre linjernas historia. Med korta linjer menar jag i detta sammanhang den mycket korta tidsrymd som sträcker sig ett decennium bakåt i tiden. Såväl väljare som politiker har möjlighet att minnas viktiga händelser och förhållanden. Likaså kan dagens aktiva politiker anses vara ansvariga för eller delaktiga i beslut som fattats. De längre linjernas historia spänner över vida tidsrymder och kan snarast antas användas som referens, symbolik och metaforik.

\section{Valrörelsen 2014}

Valrörelsen 2014 utgjorde inget undantag när det gäller att använda historiska referenser. Under de tre sista månaderna före valet i september 2014 innehöll 23 av partiledarnas totalt 30 debattartiklar i Dagens Nyheter och Svenska Dagbladet referenser till det förflutna. Referenserna varierar från att i en bisats ge ett exempel ur det förflutna till att bygga upp argumentationen med utgångspunkt $\mathrm{i}$ historiska linjer. Alliansens företrädare står för hälften av artiklarna med historiska referenser, de rödgröna för något färre och Sverigedemokrater och Feministiskt initiativ för enstaka.

I artiklarna behandlas en vid palett av ämnen, från kritik mot valsystemet, via frågor om skolan, svenska för invandrare (SFI), miljö, vård, ekonomi, arbetsmarknad, livsmedel och kriminalpolitik, till utrikes-, freds- och försvarsfrågor. Numerärt sett var frågor om skolan mest frekvent förekommande följt av utrikes- och försvarsfrågor. Endast i ett fåtal artiklar använder partiledarna historiska referenser när det gäller miljöfrågor. Miljöfrågan torde gå att rama in och argumentera för med hänvisningar till den svenska rena naturen samt till traditionen med allemansrätten, friluftsliv och livsmedel av hög kvalitet. Måhända finns rädslan att en sådan argumentation skulle peka mot en traditionell eller omodern syn på samhället. Ofta paketeras miljöfrågan som en framtidsfråga och försiktigheten med det bakåtblickande blir tydlig.

I de 23 artiklarna ger man historiska referenser i huvudsak ringa eller mellanstor vikt. Det historiska perspektivet tillmäts stor vikt i artiklar som behandlar skolkvalitet ${ }^{12}$

11 Faber, 1978, s. 44-64.

12 Till exempel SvD 29/6 2014, DN 2/9 2014. 
(SAP), sjukvårdsorganisation ${ }^{13}(\mathrm{KD})$, skärpt lagstiftning mot inbrott ${ }^{14}$ (alliansen), arbetsmarknadspolitik $^{15}(\mathrm{M})$ och NATO-medlemskap ${ }^{16}$ (FP).

Det råder ett samband mellan att lägga stor vikt vid de historiska referenserna och den funktion som de fyller i debattartiklarna. I exemplen ovan använder man historia främst som ett argument. Man drar slutsatser av det förflutna, man hämtar argument för kontinuitet eller tar man avstånd från något icke önskvärt. I exemplet nedan låter man det förflutna utgöra just argument:

Finland och Sverige anslöt sig till EU år 1995. Två länder som tror på demokrati, individuell frihet, tolerans, marknadsekonomi, rättsstat och socialt välfärdssamhälle, kort sagt vi tror på den liberala samhällsmodellen. Det är denna samhällsmodell med dess humanistiska värderingar som EU men även Nato byggt upp för att värna om att våra barn och barnbarn också ska få växa upp i frihet.

Slutsatsen av såväl andra världskriget som av det kalla kriget är att demokratierna måste hålla ihop. Demokratins väsen är att lösa konflikter genom dialog, inte med vapenmakt, men när demokratin hotas måste även demokratier kunna skydda sig, annars kommer auktoritära krafter att ta över.

\section{Jan Björklund \& Carl Haglund SvD 7 augusti 2014}

När det gäller ekonomi, HBTQ-frågor och vissa skolfrågor utgör de historiska referenserna istället exempel och då med funktionen att sätta in läsaren i sammanhang samt att förklara problemställningar och budskap: ${ }^{17}$

Skolan var redan under tidigt 2000-tal i behov av stora reformer och investeringar. Men i stället valde regeringen Reinfeldt att lägga 20 gånger mer på skattesänkningar än på skolsatsningar, samtidigt som kommunernas ekonomi drabbades av ökade socialbidragskostnader. I stället drabbades skolan av hafsiga regeländringar, ökad vinstjakt och billig symbolpolitik. Det är ett moraliskt val, som bidrar till att de 125000 barn som föds i år tillhör en generation som kan få det sämre ställt än sina föräldrar. Men så behöver det inte bli. Vi kan göra ett annat val. Vi kan skapa förändring, så att nästa generation får det bättre.

Stefan Löfvén et al. DN 2 september 2014

Artikelns budskap visar på den bild som SAP vill ge av läget. Man redovisar ett problem, men det förflutna utgör i sig inget argument.

Anknytningar och hänvisningar till historien görs i huvudsak genom korta historiska linjer (vilka i de här exemplen utgörs av det senaste decenniet) som sammanfaller väl

13 SvD 30/6 2014.

14 DN 23/6 2014.

15 SvD 3/7 2014.

16 SvD 7/8 2014.

17 Exempelvis SvD 1/7 2014, SvD 3/7 2014, DN 30/7 2014, 1/8 2014, DN 2/9 2014. 
med frågor om ekonomi, skola, kriminalpolitik och miljö. ${ }^{18}$ De historiska hänvisningarna har här inte någon stark metaforisk kraft, utan beskriver den dagliga politiska diskussionen och relaterar till frågor som väljarna kan ha i minnet.

De något längre historiska linjerna (här längre än ett årtionde) används däremot i andra frågor. De är tämligen lätträknade, men relaterar till mer välkända historiska händelser. Som citatet ovan om NATO-medlemskap visar knyter Folkpartiet an till erfarenheter efter andra världskriget, i synnerhet demokratiernas samarbete i syfte att skydda just demokratin. ${ }^{19}$ Alliansens plädoajé för en ansvarsfull ekonomisk politik liksom för vikten av arbete innehåller tillbakablickar till 1930-talets krisår. ${ }^{20}$ På motsvarande sätt tar Göran Hägglund utgångspunkt i 1830-talets sjukvårdsorganisation då han argumenterar för att det är hög tid att förändra densamma. ${ }^{21}$ Frågor om fred och försvar, arbetsmarknad samt sjukvård är i flera avseenden traditionellt gemenskapande frågor i det svenska samhället. De långa historiska linjerna utgör förhållandevis icke-kontroversiella berättelser som många kan förväntas acceptera. Dessa linjer fyller också funktionen som stärkande argument.

\section{Hur historiska referenser används}

När det gäller hur partiledarna använder sig av historiska referenser kan en grov indelning göras i ett positivt och förankrande respektive ett negativt och avståndstagande historiebruk. Det förstnämnda tillämpas i större utsträckning av alliansens företrädare, viket är förväntat med tanke på att man har regerat under de senaste två mandatperioderna. Alliansens partiledare använder historien bland annat i form av referenser till just den egna regeringsperiodens reformer och framsteg. Man är också ensam om att knyta an till en längre svensk politisk tradition av fred, trygghet och en förhållandevis lugn arbetsmarknad.

Det negativa avståndstagande historiebruket förekommer endast i en knapp tredjedel av det totala antalet artiklar med historiska referenser. Här finns en övervikt av oppositionens partiledare, varav MP har skrivit fler artiklar än Fi, SAP och SD. Endast i ett fåtal av dessa artiklar går man i polemik med utvecklingen under alliansåren och använder den som argument. Denna typ av historiebruk ökar dock något under valrörelsens sista två veckor. Artiklarna behandlar bland annat alliansens skolpolitik och förändringar i arbetet mot hatbrott. ${ }^{22}$ Ett tydligt uttryck för polemik med den politik som förts under de senaste mandatperioderna ger Åsa Romsson, Isabella Lövin och Maria Wetterstrand från Miljöpartiet:

18 DN 5/9 2014, DN 14/6 2014, Svd 14/6 2014.

19 SvD 7/8 2014.

20 DN 21/8 2014.

21 SvD 30/6 2014.

22 DN 2/9 2014, DN 5/9 2014 och SvD 7/9 2014. 
2009 lovade Reinfeldt att Sverige skulle betala sin andel av FN:s klimatfinansiering för att hjälpa fattiga länder att möta klimathotet och hoppa över fossil energi i sin utveckling för att i stället gå direkt på förnybart. Finansieringen ska enligt avtalet ske utanför biståndet, men hittills har alliansen inte levererat en enda ny krona. I Miljöpartiets budgetförslag prioriteras den finansiering som är utlovad.

\section{Åsa Romson et al. DN 5 septermber 2014}

Andra avståndstagande historiebruk rör erfarenheter av tidigare europeiska krig och de numera alltmer frekventa terrorhoten, vilka Fp-ledaren vänder sig mot då han förespråkar ökat mellanstatligt samarbete och ett svenskt medlemskap i NATO.23

Under kvartalet före riksdagsvalet 2014 agerade partiledarna i genomsnitt var tredje dag på de stora rikstidningarnas debattsidor. I huvuddelen av debattartiklarna hänvisade man till historien, företrädesvis den nära men också i form av längre historiska linjer. Det råder ett samband mellan att ge de historiska perspektiven förhållandevis stort utrymme, att använda längre historiska linjer och att låta dessa utgöra argument. Något grovt beskrivet kännetecknar denna beskrivning alliansens historiebruk. De rödgröna hänvisar till det senaste decenniet, använder det förflutna som exempel och i mer begränsad utsträckning. Sverigedemokrater och Fi, däremot, gör ytterst få referenser till det förflutna. I valet 2014 verkar det inte ha varit till deras nackdel.

23 SvD 14/8 2014 